\title{
Effects of alpha fetoprotein on escape of Bel 7402 cells from attack of lymphocytes Mengsen $\mathrm{Li}^{\dagger 1}$, Xinhua Liu ${ }^{\dagger 1}$, Sheng Zhou ${ }^{2}$, Pingfeng $\mathrm{Li}^{1}$ and Gang Li*1
}

Address: ${ }^{1}$ Department of Biochemistry and Molecular Biology, Peking University Health Science Center, Beijing 100083, China and ${ }^{2}$ Department of Biochemistry, Hainan Medical College, Haikou 570102, China

Email: Mengsen Li - ligang55@263.net; Xinhua Liu - ligang55@263.net; Sheng Zhou - ligang55@263.net; Pingfeng Li - ligang55@263.net; Gang Li* - ligang55@263.net

* Corresponding author †Equal contributors

Published: 05 August 2005

BMC Cancer 2005, 5:96 doi:10.1/86/147|-2407-5-96
Received: 08 April 2005

Accepted: 05 August 2005

This article is available from: http://www.biomedcentral.com/I47/-2407/5/96

(C) $2005 \mathrm{Li}$ et al; licensee BioMed Central Ltd.

This is an Open Access article distributed under the terms of the Creative Commons Attribution License (http://creativecommons.org/licenses/by/2.0), which permits unrestricted use, distribution, and reproduction in any medium, provided the original work is properly cited.

\begin{abstract}
Background: Involvement of AFP against apoptosis of tumor cell has been implicated in its evasion of immune surveillance. However, the molecular events of immune escape mechanisms are still unknown. The major observations reported here relate to a possible mechanism by which heptoloma Bel 7402 cells escape immune surveillance in vitro.
\end{abstract}

Methods: Western blotting and a well-characterized cofocal scanning image were performed to analyze the expression of Fas/FasL and caspase-3 in co-cultured Bel 7402 and Jurkat cells.

Results: After co-culture with Jurkat cells, up-regulated Fas and reduced FasL expression could be observed. Treatment with AFP could remarkably inhibit the elevated Fas and, whereas, induce the FasL expression in co-cultured Bel 7402 cells. Cells co-culture could induce the expression of caspase-3 in both cells line. The elevated caspase-3 in Bel 7402 cells was abolished following the treatment of AFP. The expression of caspase- 3 was elevated in co-cultured Jurkat cells treated with AFP. No detectable change on the expression of survivin was examined in both cells line. Monoclonal antibody against AFP treatment alone did not obviously influence the growth of cells, as well as the expression of Fas/FasL and caspase-3. However, the effect of AFP could be blocked by antibody.

Conclusions: our results provide evidence that AFP could promote the escape of liver cancer cells from immune surveillance through blocking the caspase signal pathway of tumor cells and triggering the Fas/FasL interaction between tumor cells and lymphocytes.

\section{Background}

Alpha fetoprotein (AFP) is one of several oncofetal proteins synthesized in large amounts by the fetus and drops in serum markedly shortly after birth. AFP as a tumorassociated fetal protein has demonstrated clinical utility as a tumor marker. Besides its role as a carrier or transporter for various serum ligands including fatty acids, retinoids, steroids, drugs, dyes and heavy metals, AFP has been reported to display growth regulatory properties. Previous studies have verified that AFP appears to functions as a growth regulator rather than only serum carrier. Multitude of cell types involving the growth and differentiation effects of AFP include placental [1], lymphoid [2], ovarian [3], uterine [4], gastric cancer [5], epidermal [6], breast cancer [7] and fetal fibroblasts [8]. Recently, some studies on the mechanisms of AFP suggested that AFP 
induced apoptosis in tumor cells independently of Fas/ Fas ligand or TNFR/TNF signaling pathway, and AFPmediated cell death involved activation of the effector caspase-3-like proteases, but was independent of upstream activation of the initiator caspase-1, caspase- 8 , and caspase-9-like proteases [9]. The intracellular mechanism of AFP involving to CAMP-PKA signaling pathway after its binding to different affinity receptors has been also reported [10].

Although the biological roles of the oncoembryonal protein AFP, including immunoregulatory functions in a variety of immune responses including the humoral and cellmediated types, have been reviewed in detail, the evidences for the role of AFP in hepatoma cells escaping from host immune surveillance are still unknown $[11,12]$. In a recent study, AFP was used as an effective tumor rejection antigen to observe its effect in T-cell immune responses, implicating a gene therapy-based strategy for hepatoma cells [13]. However, the over-expression of AFP in human hepatoma cells is concurrent with aberrant growth manifestation. We presume that the altered serum AFP level is the cause of such changes rather than a coincident phenomenon and should be responsible for the malignant progression of liver cancer. Thus revealing the intracellular mechanisms underlying the evasion of tumor from host immune surveillance will provide further insights into the understanding for the biological role of AFP, particularly in the case of hepatocellular carcinomas.

\section{Methods}

\section{Determination of cells proliferation}

Jurkat T cells and Bel 7402 cells, the human hepatoma cell line, were adjusted to $3.0 \times 10^{4}$ per $\mathrm{ml}$ separately and maintained in PRMI-1640 medium supplemented with $10 \%$ heat-inactivated fetal bovine serum. The cells were seeded into 24 -well plates and incubated at $37^{\circ} \mathrm{C}$ in a humidified atmosphere of $5 \% \mathrm{CO}_{2}$. The supernatant was replaced to RPMI-1640 medium free serum for $24 \mathrm{~h}$, then the various concentrations $(5,10,20,40,80$ or $100 \mathrm{mg} / \mathrm{L})$ of AFP (Biodesign International Co. USA), human serum albumin (HSA, from Sigma, USA) and anti-AFP antibody (Santa Cruz. USA) were administrated into Jurkat T cells and Bel 7402 cells for $60 \mathrm{~h}$ respectively. The viability of cells was determined by Trypan blue exclusion assay.

\section{Cell co-culture assay}

To observe the effect of AFP on the escape of tumor cell from the attack of lymphocytes, $1.5 \times 10^{4}$ of Jurkat calls and equal Bel 7402 cells that grew under such conditions were mixed and co-cultured onto 24 -well plate. Following the incubation in RPMI-1640 medium for $24 \mathrm{~h}$, AFP (20 $\mathrm{mg} / \mathrm{L})$, HSA (20 gm/L), AFP (20 mg/L) plus anti-AFP antibody $(40 \mathrm{mg} / \mathrm{L})$ and anti-AFP antibody $(40 \mathrm{mg} / \mathrm{L})$ were added into culture for $60 \mathrm{~h}$. The fraction containing Jurkat cells were removed from flask by resuspending the supernatant gently and transferring the supernatant to a centrifuge tube. Bel 7402 cells in the bottom were scraped and collected. The viability of each cell line was determined by Trypan blue exclusion.

\section{Determination of Fas and FasL expression}

Bel 7402 cells and Jurkat $\mathrm{T}$ cells were co-cultured as described above in Petri dish. AFP $(20 \mathrm{mg} / \mathrm{L})$, HSA $(20$ $\mathrm{mg} / \mathrm{L})$, AFP $(20 \mathrm{mg} / \mathrm{L})$ plus anti-AFP antibody $(40 \mathrm{mg} / \mathrm{L})$ and anti-AFP antibody $(40 \mathrm{mg} / \mathrm{L})$ were added into culture. At 48 hours treatment, Bel 7402 cells were washed 3 times with RPMI-1640 free serum to remove Jurkat cells. Cells were incubated with $0.5 \mathrm{ml}$ of rabbit anti-Fas or anti-FasL solution (Santa Cruz Co, USA. 1:250 in RPMI-1640 medium) for $1 \mathrm{~h}$. After washing with medium 3 times at room temperature, secondary goat anti-rabbit IgG antibodies conjugated with FITC (Santa Cruz, USA) were applied, and incubated for 1 hour at $37^{\circ} \mathrm{C}$. After washing with PBS, the cells were observed under Confocal Laser Scanning Microscope (Leica TCS-NT SP2, Germany).

\section{Western blot immunodetection}

$1.5 \times 10^{4}$ Jurkat T cells and $1.5 \times 10^{4} \mathrm{Bel} 7402$ cells per ml were co-cultured in $75-\mathrm{cm}^{2}$ flasks and maintained in RPMI-1640 medium free serum for $24 \mathrm{~h}$. To replace the supernatant with medium supplemented with $10 \%$ FCS, the supernatant which containing the Jurkat cells were removed, centrifuged and resuspended with fresh medium. The suspension was replaced into flasks to remix with Bel 7402 cells. Afterward, the co-cultured cells were treated with AFP $(20 \mathrm{mg} / \mathrm{L})$, HSA (20 gm/L), AFP $(20 \mathrm{mg} /$ L) plus anti-AFP antibody $(40 \mathrm{mg} / \mathrm{L})$ and anti-AFP antibody $(40 \mathrm{mg} / \mathrm{L}$ ) for $36 \mathrm{~h}$ respectively. Proteins were quantified before being loaded onto the gel. $40 \mu \mathrm{g}$ of extracted proteins from each group was loaded onto $10 \%$ SDS polyacrylamide gels. Proteins were blotted onto a nitrocellulose membrane (Amersham, UK). Membranes were incubated for $1 \mathrm{~h}$ with anti-caspase-3 or anti-survivin monoclonal antibodies (Santa Cruz Co. USA) and then washed and revealed using anti-rabbit IgG horseradish peroxidase conjugate. Immunoreaction protein was detected by the chemiluminescence luminol reagent (Santa Cruz, USA).

\section{Statistical analyses}

All experiments were performed at least three times. Data were presented as mean $\pm \mathrm{SD}$. The significance of the difference between experimental and control groups was analyzed with Student's $t$ test. A value of $p<0.05$ was considered to be statistically significant. 
A

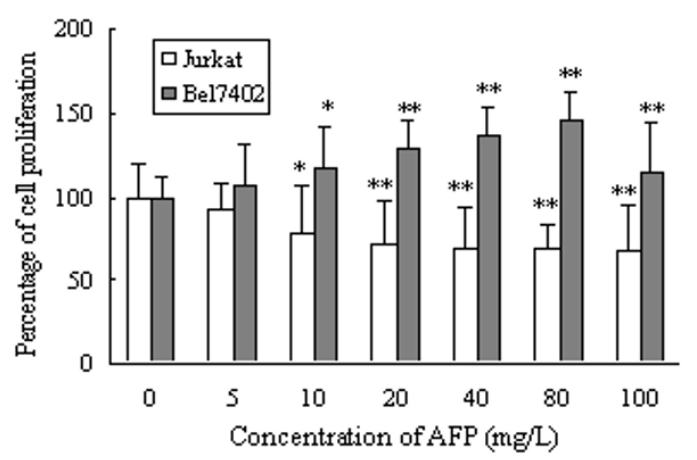

B

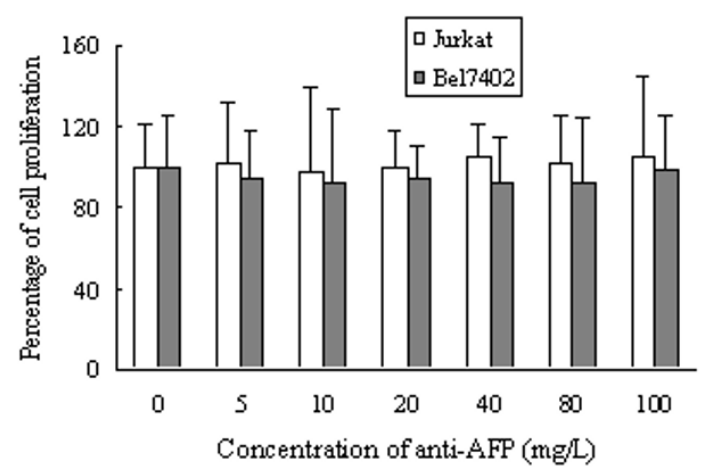

$\mathrm{C}$

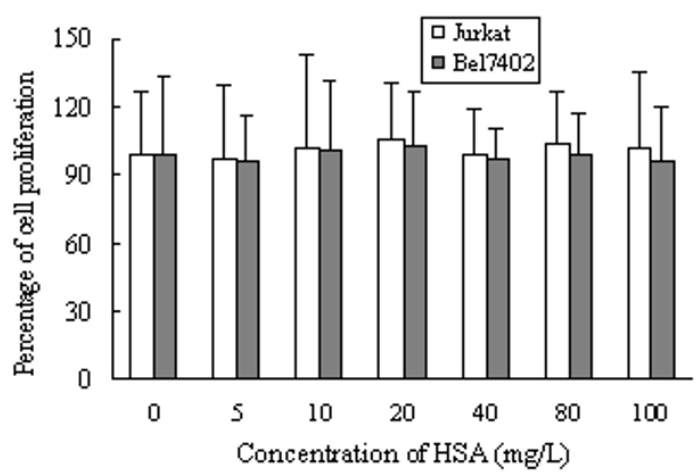

Figure I

The effects of different concentrations of AFP on the growth of cells. The viability of Jurkat and Bel 7402 cells were observed after treated with different concentrations $(5,10$, $20,40,80$ or $100 \mathrm{mg} / \mathrm{L}$ ) of either AFP (A), anti-AFP antibody (B) or HSA (C) for $60 \mathrm{~h}$ at $37^{\circ} \mathrm{C}$ in a humidified atmosphere of $5 \% \mathrm{CO}_{2} * *<<0.05$ and $* * P<0.01$ vs corresponding to normal control $(0 \mathrm{mg} / \mathrm{L})$ analyzed by $t$-test. Data were representative of an experiment that was repeated three times presented as mean \pm SD of 12 samples.

\section{Results}

The effects of AFP on the proliferation of cells

AFP could enhance the proliferation of Bel 7402 cells in the dose-dependent manner in the concentration range of 10 to $80 \mathrm{mg} / \mathrm{L}$ (Fig 1A). The increment was up to $46.8 \%$ $(80 \mathrm{mg} / \mathrm{L})$ compared with control. However, the inhibited effect of AFP was observed in the growth of Jurkat cells. The maximum suppressive dose might be observed at the concentration of $80 \mathrm{mg} / \mathrm{L}$ ( $30.6 \%$ inhibition). As the controls, HSA and anti-AFP antibody did not display any detectable influences on the cell growth (Fig 1B and 1C).

\section{The effects of AFP on the growth of co-cultured cells}

To observe the effects of AFP on the escape of Bel 7402 cells from the attack of lymphocytes, AFP at a concentration of $20 \mathrm{mg} / \mathrm{L}$, which has been reported and proved to be an optimal dose according to the dose response curves in our recent experiments [unpublished data], was added into co-cultured cells. Jurkat and Bel 7402 cells were separated as described in Materials and Methods after the treatment of $60 \mathrm{~h}$ and the viability of each cell was determined. The results showed that the growths of both cells in untreated group were inhibited in the cells co-culture (Fig 2 ). However, the administration of AFP could obviously inhibit the proliferation of Jurkat cells, but not Bel 7402 cells after cells co-culture. Anti-AFP antibody could block the effect of AFP on cell proliferation. Antibody alone and HSA did not display any significant influences on the cell growth.

\section{Fas/FasL expression in Bel $\mathbf{7 4 0 2}$}

AFP was added into either separate-cultured or co-cultured cells to observe its effects on the expression of Fas and FasL in Bel 7402 under confocal fluorescent microscope. As shown in Fig 5, untreated cells cultured separately did not exhibit green fluorescence on the surface of Bel 7402 (Fig 3A). After the administration of AFP for 48 h, only a diffuse image could be observed (Fig 3B). Bel 7402 cells co-cultured with Jurkat cells for 90 min exhibited an ever-increasing green fluorescence throughout the time course that reflected the presence of expressed Fas, which was faded after the addition of AFP (Fig 3E and 3C). Anti-AFP antibody alone did not change the fluorescent intensity of image and however, could partly reverse the effect of AFP on the expression of Fas (Fig 3D and 3F). In the observation of FasL, separate-cultured Bel 7402 cells did not display the expression of FasL (Fig 4A). The slight green outline of cells was observed after the addition of AFP (Fig 4B). The cell co-culture could induce the expression of FasL in Bel 7402 cells (Fig 4C). However, Bel 7402, in contrast with that observed in the assay of Fas, co-cultured with Jurkat cells in the presence of AFP could show an enhanced green fluorescent. A representative image is shown in Fig 4D. 


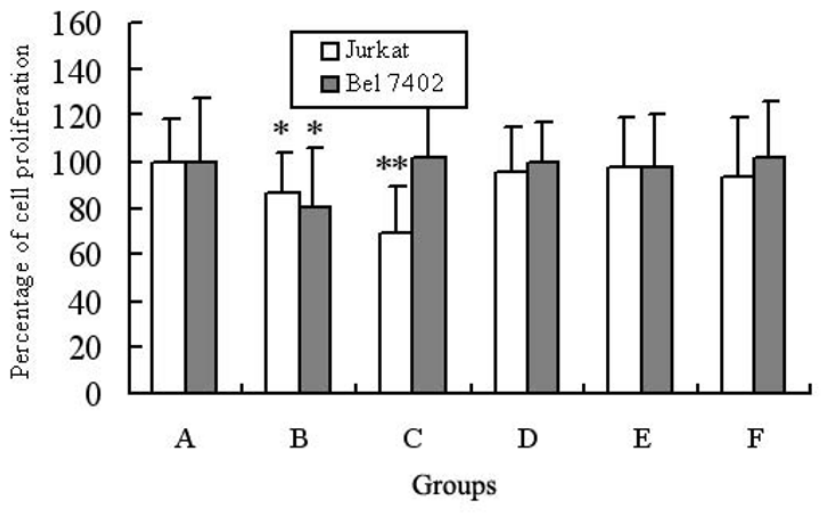

Figure 2

The effects of AFP on the co-cultured cells. Bel 7402 and Jurkat cells were co-cultured for $24 \mathrm{~h}$ following treated with AFP (20 mg/L) (C), AFP (20 mg/L) plus anti-AFP antibody (40 $\mathrm{mg} / \mathrm{L})(\mathrm{D})$, anti-AFP antibody $(40 \mathrm{mg} / \mathrm{L})(\mathrm{E})$ and HSA (20 gm/ L) (F) respectively. Graph bar A represents the viability of separate-cultured cells. Graph bar B represents co-cultured and no-treatment group. After $60 \mathrm{~h}$, two cell lines were separated and the viability of each cell was observed respectively. $* P<0.05$ and $* * P<0.0$ I vs corresponding to normal control $(0 \mathrm{mg} / \mathrm{L})$ analyzed by $t$-test. Data were representative of an experiment that was repeated three times presented as mean \pm SD of 12 samples.

\section{Immunodetection of apoptosis-related proteins}

When different cells were separately cultured, AFP could enhance the intracellular expression of caspase-3 in Jurkat cells and suppress that in Bel 7402 cells (Fig 5). In the coculture experiment, the contents of caspase- 3 in both cell lines were increased even though no AFP treatment. As shown by the intensities of the immuno-positive bands, the synthesis of intracellular caspase- 3 in Jurkat cells was potently up-regulated after the administration of AFP. In contrast, no detectable change in the content of caspase- 3 could be observed in the co-cultured Bel 7402 cells, indicating the block of AFP. The effect of AFP on the expression of caspase- 3 in both cells could be abolished by antiAFP antibody. As shown in Fig 6, AFP did not display significant influence on the level of survivin although a slight increment in co-cultured Jurkat cells.

\section{Discussion}

During the last decade, it has been confirmed from a multitude of studies that AFP as a growth regulator modulates the ontogenic growth and tumor progression even though the overall findings remain controversial and their interpretations are still being debated. Previous studies also implicated that AFP expressed during pregnancy inhibits the maternal immune exclusion by suppressing immune responses of the humoral and cell-mediated types [14]. The higher level of AFP in the serum of liver cancer subject has been considered to be the reason of tumor development rather than merely the concomitant oncofetal protein. Hereby, the implication was emerged that AFP functions to constitute one of fundamental steps in the progression of hepatoma. It is in fact that one of mechanisms of progression and development of liver cancer is due to its escaping from immune surveillance. Experimental results obtained from the present study showed that AFP was capable of suppressing the growth of Jurkat cells with the concomitant proliferation of Bel 7402, indicating the diversity effects of AFP on the regulation of immune and tumor cells growth. This result was supported by a recent study, which indicated that AFP induced significant apoptosis of dendritic cells [15]. AFP-treated dendritic cells could produce low levels of IL-12 and TNF- $\alpha$, a cytokine pattern that could hamper an efficient antitumor immune response. These results thereby offered a mechanism by which hepatocellular carcinoma escapes immunological control.

Co-culture experiment has been widely used for the determination of apoptosis, pathological response and tumor related protein synthesis [16-18]. The effects of Fas/FasL in the mechanism of tumor escaping from immune surveillance have been extensively documented [19-22]. It has been proposed that the expression of Fas/FasL in tumors may play a critical role in immune escape. In the present study, the expression of Fas/Fas L in target hepatoma Bel 7402 cells was examined after co-culture with the effector Jurkat cells in vitro. Our data showed that the expression of membrane Fas was enhanced in Bel 7402 cells co-cultured with Jurkat cells. The fact that the enhanced expression of Fas was abolished by AFP exposure indicated that the stimulation of Jurkat cells to Bel 7402 cells was able to be blocked by AFP. This is in accordance with our recent findings from immunodetection analysis (unpublished data). On the other hand, AFP enhanced the synthesis of FasL in Bel 7402 cells, which was consistent with previous findings [23-27]. AFPinduced over-expression of Fas on the surface of lymphocytes, together with simultaneous over-secreted FasL from tumor cells, could be one of reasons to accelerate the death of lymphocytes and facilitate the immune escape of liver cancer. This conclusion is supported by a recent study, which indicated that Fas-mediated apoptosis resulted by cancers expressing FasL and killing lymphocytes was irrespective of transforming growth factorbeta1 (TGF-beta1) expression [28].

Although the precise mechanism of AFP-mediated cell growth regulation and apoptosis induction remains 

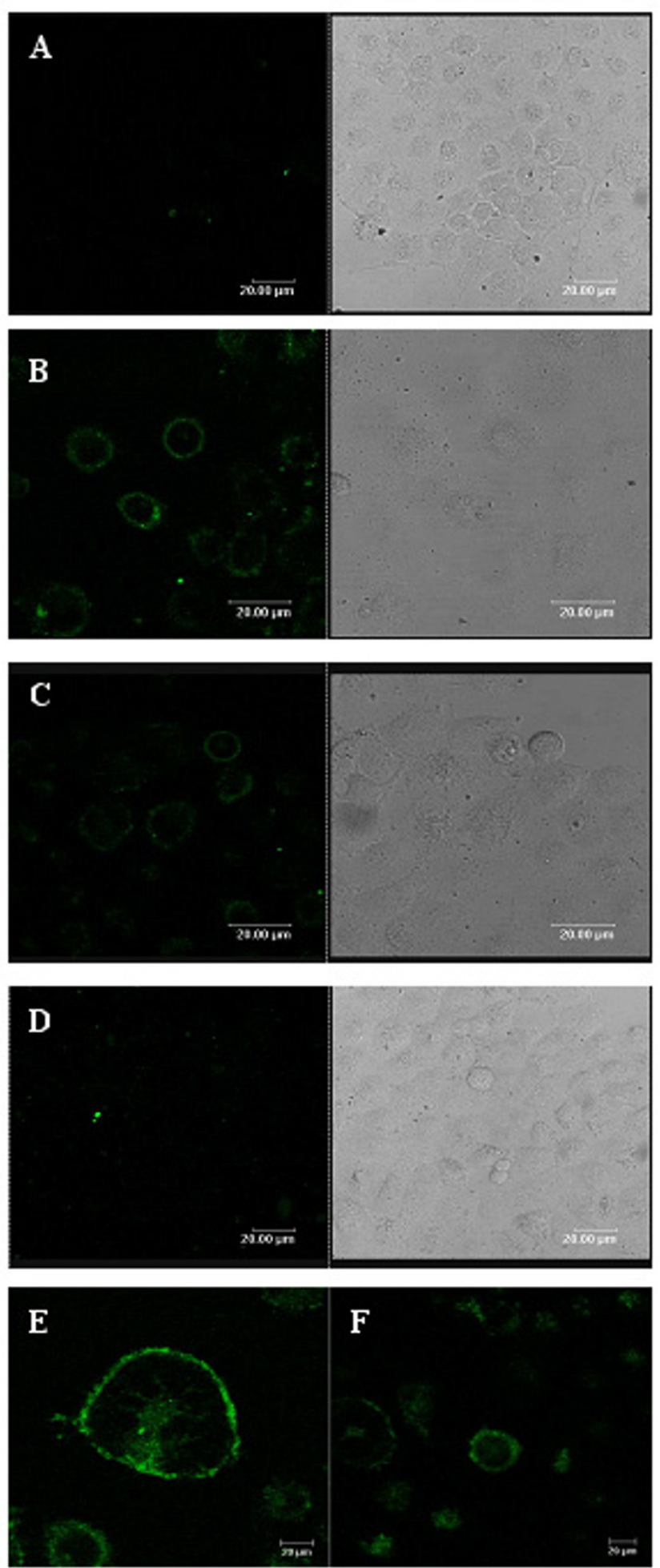

\section{Figure 3}

Confocal assay for the expression of Fas on the membrane of co-cultured Bel 7402 cells. Bel 7402 cells and Jurkat T cells were co-cultured with AFP (20 mg/L), anti-AFP antibody (40 $\mathrm{mg} / \mathrm{L})$, and AFP (20 mg/L) plus anti-AFP antibody (40 mg/L) respectively for $48 \mathrm{~h}$. After removing Jurkat cells, Bel 7402 cells were incubated with rabbit anti-Fas antibody and secondary goat anti-rabbit IgG antibodies conjugated with FITC. The cells were observed using a confocal laser scanning microscope. Image A: separate-cultured Bel 7402 cell; B: separate-cultured Bel 7402 cells treated with AFP; C: co-cultured Bel 7402 cells treated with AFP; D: co-cultured Bel 7402 cells treated with anti-AFP antibody. Right images from $A$ to $D$ were taken under common microscope to observe the state of cells. E: co-cultured Bel 7402 cells; F: co-cultured Bel 7402 cells treated with AFP and anti-AFP antibody. All images were representative of an experiment that was repeated three times.

obscure, there have been considerable investigations indicating that AFP can modulate apoptotic signals induced by various factors by either promoting or abrogating apoptosis. In the present study, the intracellular level of caspase- 3 in Bel 7402 cells after co-culture with Jurkat cells was up-regulated, indicating the inducement of the apoptotic protein by lymphocytes. Furthermore, the pretreatment of AFP in vitro in co-cultured cells led to the full abolishment of caspase-3. Whereas, an increment at the level of caspase-3 protein was observed in co-cultured Jurkat cells after stimulated by AFP, which resulted in the depletion of lymphocytes in culture. The accelerated death of lymphocytes in current study might serve to certify the speculation that AFP-mediated apoptosis involved activation of the effector caspase-3-like proteases [9]. Therefore, it is reasonable to postulate that the escaping of tumor cells from immune surveillance is partly attributable to the apoptosis of lymphocytes induced by AFP. Taking into consideration the ability of AFP to alter the Fas/ FasL expression in Bel 7402 and Jurkat cells, the signaling pathway involved might be initiated through the interaction of AFP with corresponding receptors and induced the activation of Fas/FasL and caspase-3 system. Our data elucidated that the death signal was triggered by activation of specific membrane AFP receptors involved in apoptosis signaling, leading to the expressional alteration of Fas/ FasL and caspase-3. These findings are in accordance with the previous data showing that Fas/FasL was involved in AFP-induced immune escape [29-31].

\section{Conclusions}

In summary, the present study has at least partly explained demonstrated the potential effect of AFP in malignant 

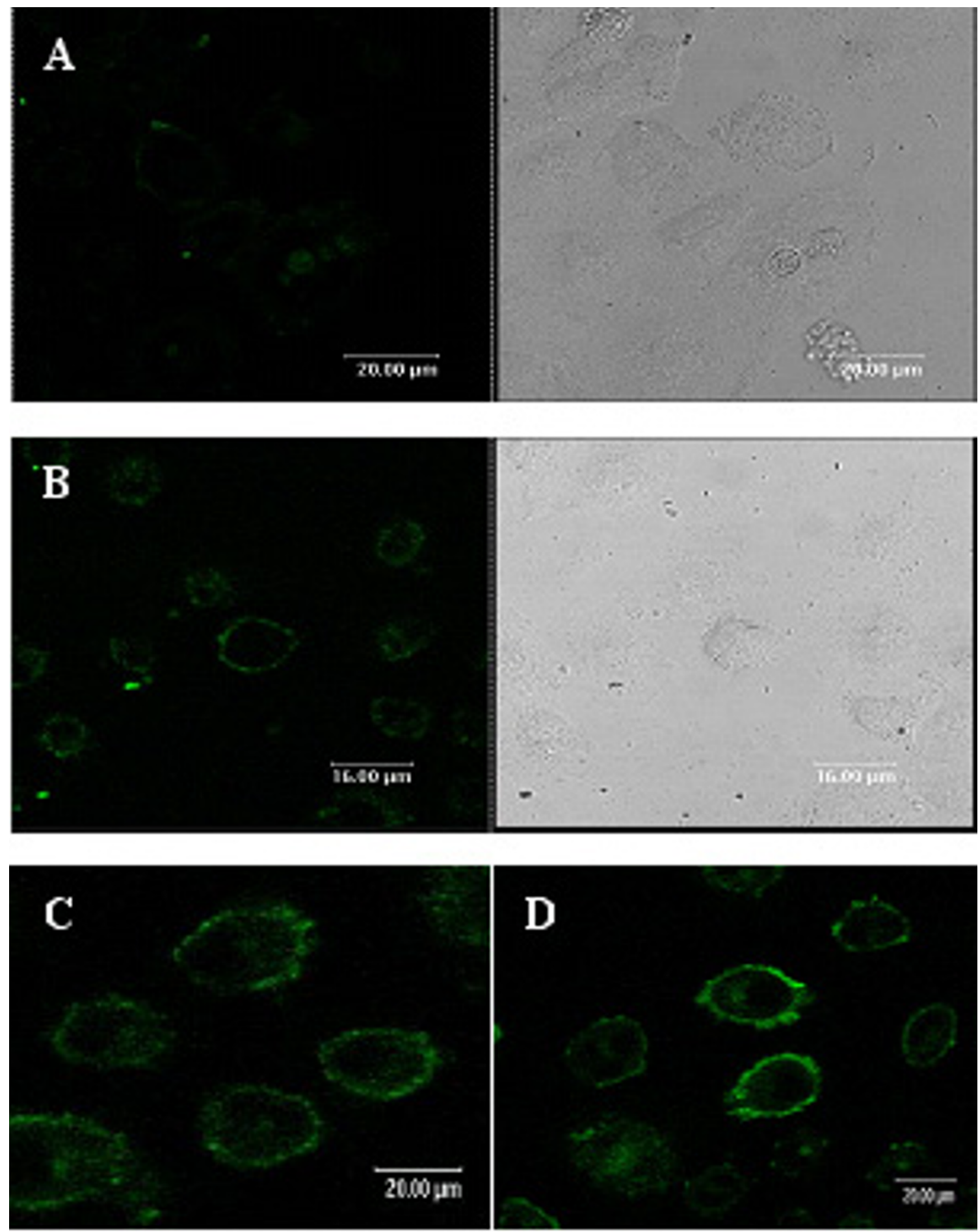

Figure 4

Confocal assay for the expression of FasL on the membrane of co-cultured Bel 7402 cells. Bel 7402 cells and Jurkat T cells were co-cultured with AFP $(20 \mathrm{mg} / \mathrm{L})$ for $48 \mathrm{~h}$. After removing Jurkat cells, Bel 7402 cells were incubated with rabbit anti-FasL antibody and secondary goat anti-rabbit IgG antibodies conjugated with FITC. The cells were observed using a confocal laser scanning microscope. Image A: separate-cultured Bel 7402 cell; B: separate-cultured Bel 7402 cells treated with AFP. Right images of $A$ and $B$ were taken under common microscope to observe the state of cells. $C$ : co-cultured Bel 7402 cells without AFP treatment; D: co-cultured Bel 7402 cells treated with AFP. All images were representative of an experiment that was repeated three times. 


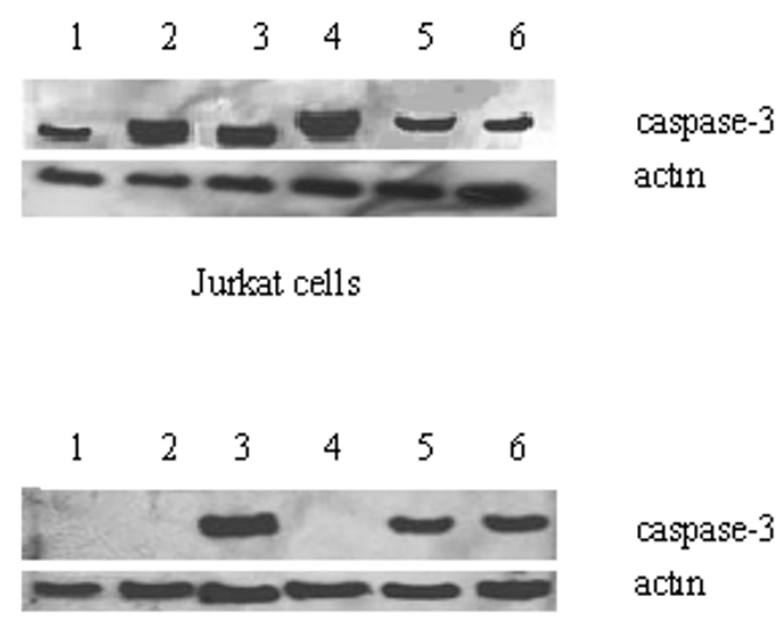

Bel 7402 cells

\section{Figure 5}

The effects of AFP on the expression of caspase- 3 protein. Jurkat T cells and Bel 7402 cells were co-cultured for $24 \mathrm{~h}$ and treated with AFP (20 mg/L), HSA (20 gm/L), AFP (20 mg/ L) plus anti-AFP antibody (40 $\mathrm{mg} / \mathrm{L})$ and anti-AFP antibody $(40 \mathrm{mg} / \mathrm{L})$ for $36 \mathrm{~h}$ respectively. The expression of caspase-3 was detected with Western blotting. Lane I: control; Lane 2: cells separate-cultured cells treated with AFP; Lane 3: co-cultured cells; Lane 4: co-cultured cells treated with AFP; Lane 5: co-cultured cells treated with AFP and anti-AFP antibody; Lane 6: co-cultured cells treated with anti-AFP antibody. All images were representative of an experiment that was repeated three times.

growth and transformation of liver tumor cell. Take together all findings, we propose that the effect of AFP in the escape of hepatoma Bel 7402 cells from immune surveillance is achieved though decreasing Fas in its membrane and secreting FasL which in turn to trigger apoptosis of lymphocytes via caspase- 3 cascade. Thus, the involvement of Fas- and caspase-related signal pathway in the occurrence of liver tumor was thereby indicated in this study. The precise elucidation of the biological effect of AFP will help to better understand the regulatory mechanism of immune surveillance in liver cancer.

\section{Abbreviations}

AFP: alpha fetoprotein; HSA: human serum albumin

\section{Competing interests}

The author(s) declare that they have no competing interests.

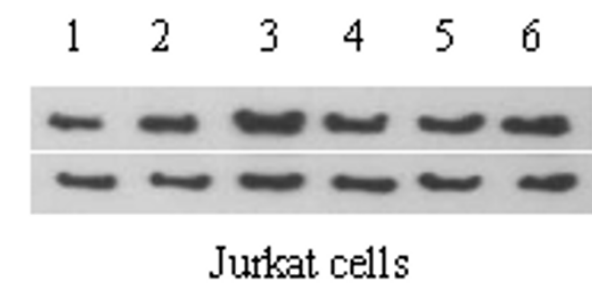

survivin

actin

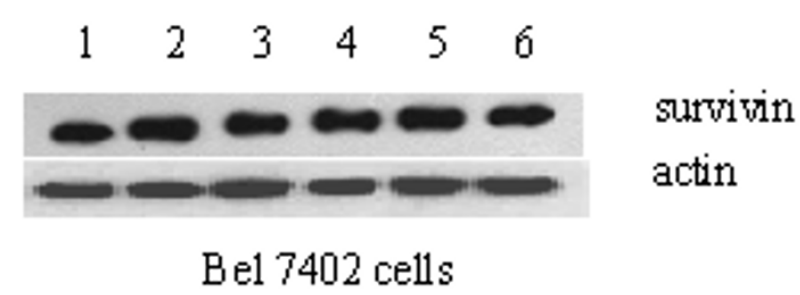

\section{Figure 6}

The effects of AFP on the expression of survivin protein. Jurkat T cells and Bel 7402 cells were co-cultured for $24 \mathrm{~h}$ and treated with AFP $(20 \mathrm{mg} / \mathrm{L})$, HSA $(20 \mathrm{gm} / \mathrm{L})$, AFP $(20 \mathrm{mg} / \mathrm{L})$ plus anti-AFP antibody $(40 \mathrm{mg} / \mathrm{L})$ and anti-AFP antibody (40 $\mathrm{mg} / \mathrm{L}$ ) for $36 \mathrm{~h}$ respectively. The expression of survivin was detected with Western blotting. Lane I: control; Lane 2: cells separate-cultured cells treated with AFP; Lane 3: co-cultured cells; Lane 4: co-cultured cells treated with AFP; Lane 5: cocultured cells treated with AFP and anti-AFP antibody; Lane 6: co-cultured cells treated with anti-AFP antibody. All images were representative of an experiment that was repeated three times.

\section{Authors' contributions}

Mengsen Li and Xinhua Liu: carried out the study and contributed equally to this study.

Sheng Zhou: participated in the statistical analysis.

Pingfeng Li: conceived of the study, and participated in its design and coordination and helped to draft the manuscript.

Gang Li: conceived and design of the study, corresponding author.

\section{Acknowledgements}

This study is partly supported by the National Natural Science Foundation of China (No.3027II 74 and 30260 II7).

\section{References}

I. Toder V, Bland M, Gold-Gefter L, Nebel J: The effect of alphafetoprotein on the growth of placental cells in vitro. Placenta 1983, 4:79-86.

2. Hamel S, Hoskin DW, Hooper DC, Murgita RA: Phenotype and function of bone marrow-derived $T$ and non- $T$ cells activated in vitro by alpha-fetoprotein. In Biological activities of alpha-fetoprotein Edited by: Mizejewski G], Jacobson HI. CRC Press: Florida; 1987:167-177. 
3. Keel BA, Eddy KB, Cho S, May JV: Synergistic action of purified $\alpha$-fetoprotein and growth factors on the proliferation of porcine granulose cells in monoplayer culture. Endocrinology 1991, | 29:217-225.

4. Mizejewski GJ, Keenan JF, Setty RP: Separation of the estrogenactivated growth regulatory forms of alpha-fetoprotein in mouse amniotic fluid. Biol Reprod 1990, 42:887-898.

5. Koide N, Nishio A, Igarashi J, Kajikawa S, Adachi W, Amano J: $\alpha$-fetoprotein-producing gastric cancer: histochemical analysis of cell proliferation, apoptosis, and angiogenesis. American J Gastroenterol 1999, 94:1658-1663.

6. Leal JA, May JV, Keel BA: Human alpha-fetoprotein enhances epidermal growth factor proliferation activity upon porcine granulose cells in monolayer culture. Endocrinology 1980, |26:669-67|.

7. Bennett JA, Semeniuk DJ, Jacobson HI, Murgita RA: Similarity between natural and recombinant human alpha-fetoprotein as inhibitors of estrogen-dependent breast cancer growth. Breast Cancer Res Treat 1997, 45:169-179.

8. Dudich E, Semenkova L, Gorbatova E, Dudich I, Khromykh L, Tatulov E, Grechko G, Sukhikh G: Growth-regulative activity of human alpha-fetoprotein for different types of tumor and normal cells. Tumour Biol 1998, 19:30-40.

9. Dudich E, Semenkova L, Dudich I, Gorbatova E, Tochtamisheva N, Tatulov E, Nikolaeva M, Sukhikh G: alpha-fetoprotein causes apoptosis in tumor cells via a pathway independent of CD95, TNFRI and TNFR2 through activation of caspase-3-like proteases. Eur J Biochem 1999, 266:750-6I.

10. Li MS, Li PF, He SP, Du GG, Li G: The intracellular mechanism of alpha-fetoprotein promoting the proliferation of NIH 3T3 cells. Cell Res 2002, 12:151-156.

II. Mizejewski GJ: Alpha-fetoprotein structure and function: relevance to isoforms, epitopes, and conformational variants. Exp Biol Med (Maywood) 200I, 226:377-408.

12. Mizejewski G], MacColl R: $\alpha$-fetoprotein growth inhibitory peptides: potential leads for cancer therapeutics. Mole cancer Ther 2003, 2: 1243-1255.

13. Vollmer CM Jr, Eilber FC, Butterfield LH, Ribas A, Dissette VB, Koh A, Montejo LD, Lee MC, Andrews KJ, McBride WH, Glaspy JA, Economou JS: Alpha-fetoprotein-specific genetic immunotherapy for hepatocellular carcinoma. Cancer Res 1999, 59:3064-7.

14. Deutsch HF: Chemistry and biology of alpha-fetoprotein. Adv Cancer Res 1991, 56:253-312.

15. Um SH, Mulhall C, Alisa A, Ives AR, Karani J, Williams R, Bertoletti A, Behboudi S: $\alpha$-Fetoprotein impairs APC function and induces their apoptosis. J Immunol 2004, 173:1772-1778.

16. Lee TB, Min YD, Lim SC, Kim KJ, Jeon HJ, Choi SM, Choi CH: Fas (Apo-I/CD95) and Fas ligand interaction between gastric cancer cells and immune cells. J Gastroenterol Hepatol 2002, 17:32-8.

17. Lim IJ, Phan TT, Bay BH, Qi R, Huynh H, Tan WTL, Lee ST, Longaker MT: Fibroblasts co-cultured with keloid keratinocytes: normal fibroblasts secrete collagen in a keloidlike manner. $\mathrm{Am} J$ Physiol Cell Physiol 2002, 283:C212-C222.

18. Thornton MV, Kudo D, Rayman P, Horton C, Molto L, Cathcart MK, $\mathrm{Ng}$ C, Paszkiewicz-Kozik E, Bukowski R, Derweesh I, Tannenbaum CS, Finke JH: Degradation of NF-kappa B in T cells by gangliosides expressed on renal cell carcinomas. The Journal of Immunology 2004, 1 72:3480-3490.

19. Uzzo RG, Rayman P, Kolenko V, Clark PE, Bloom T, Ward AM, Molto L, Tannenbaum C, Worford L), Bukowski R, Tubbs R, Hsi ED, Bander $\mathrm{NH}$, Novick AC, Finke JH: Mechanisms of Apoptosis in T Cells from Patients with Renal Cell Carcinoma. Clinical cancer research 1999, 5:1219-1229.

20. Chen YL, Chen SH, Wang JY, Yang BC: Fas ligand on tumor cells mediates inactivation of neutrophils. J Immunol 2003, |7|: || 183-9|.

21. Elnemr A, Ohta T, Yachie A, Kayahara M, Kitagawa H, Ninomiya I, Fushida S, Fujimura T, Nishimura G, Shimizu K, Miwa K: Human pancreatic cancer cells express non-functional Fas receptors and counterattack lymphocytes by expressing Fas ligand; a potential mechanism for immune escape. Int-J-Oncol 200I, 18:33-9.

22. Perabo FG, Kamp S, Schmidt D, Lindner H, Steiner G, Mattes RH, Wirger A, Pegelow K, Albers P, Kohn EC, von-Ruecker A, Mueller SC: Bladder cancer cells acquire competent mechanisms to escape Fas-mediated apoptosis and immune surveillance in the course of malignant transformation. Br J Cancer 200I, 84(10): 1330-8.

23. Ito $\mathrm{Y}$, Monden $\mathrm{M}$, Takeda $\mathrm{T}$, Eguchi $\mathrm{H}$, Umeshita $\mathrm{K}$, Nagano $\mathrm{H}$ Nakamori S, Dono K, Sakon M, Nakamura M, Tsujimoto M, Nakahara M, Nakao K, Yokosaki Y, Matsuura N: The status of Fas and Fas ligand expression can predict recurrence of hepatocellular carcinoma. Br J Cancer 2000, 82:121I-I217.

24. Patel T: Immune escape in hepatocellular cancer: is a good offense the best defense? Hepatology 1999, 30:576-578.

25. Lee SH, Shin MS, Lee HS, Bae JH, Lee HK, Kim HS, Kim SY, Jang JJ, Joo M, Kang YK, Park WS, Park JY, Oh RR, Han SY, Lee JH, Kim SH, Lee JY, Yoo NJ: Expression of Fas and Fas-related molecules in human hepatocellular carcinoma. Hum Pathol 2001, 32:250-256.

26. Fukuzawa $K$, Takahashi $K$, Furuta $K$, Tagaya $T$, Ishikawa $T$, Wada $K$, Omoto Y, Koji T, Kakumu S: Expression of fas/fas ligand (fasL) and its involvement in infiltrating lymphocytes in hepatocellular carcinoma (HCC). J Gastroenterol 200 I, 36( I0):68I-688.

27. Nagao M, Nakajima $Y$, Hisanaga M, Kayagaki N, Kanehiro H, Aomatsu Y, Ko S, Yagita H, Yamada T, Okumura K, Nakano H: The alteration of Fas receptor and ligand system in hepatocellular carcinomas: How do hepatoma cells escape from the host immune surveillance in vivo? Hepatology 1999, 30:413-421.

28. Houston A, Bennett MW, O'Sullivan GC, Shanahan F, O'Connell J: Fas ligand mediates immune privilege and not inflammation in human colon cancer, irrespective of TGF-beta expression. BrJ Cancer 2003, 89: |345-5।.

29. Semenkova L, Dudich E, Dudich I, Tokhtamisheva N, Tatulov E, Okruzhnov Y, Garcia-Foncillas J, Palop-Cubillo JA, Korpela T: Alphafetoprotein positively regulates cytochrome c-mediated caspase activation and apoptosome complex formation. Eur J Biochem 2003, 270:4388-99.

30. $\mathrm{Wu} \mathrm{J}$, Chen Y, Li T: Expression of Fas, p53 and AFP in development of human fetal germ cells in vitro. Zygote 2002, 10:333-40.

31. Li MS, Li PF, He SP, Du GG, Li G: The promoting molecular mechanism of alpha-fetoprotein on the growth of human hepatoma Bel $\mathbf{7 4 0 2}$ cell line. World J Gastroenterol 2002, 8:469-475.

\section{Pre-publication history}

The pre-publication history for this paper can be accessed here:

http://www.biomedcentral.com/1471-2407/5/96/prepub

Publish with BioMed Central and every scientist can read your work free of charge

"BioMed Central will be the most significant development for disseminating the results of biomedical research in our lifetime. "

Sir Paul Nurse, Cancer Research UK

Your research papers will be:

- available free of charge to the entire biomedical community

- peer reviewed and published immediately upon acceptance

- cited in PubMed and archived on PubMed Central

- yours - you keep the copyright

Submit your manuscript here:

http://www.biomedcentral.com/info/publishing_adv.asp 